\title{
IMPEDIMENTS TO PUBLIC CONSULTATIONS IN THE POLISH LOCAL SELF-GOVERNMENT
}

\author{
Marcin Pomaranski \\ Maria Curie-Sklodowska University in Lublin, Poland
}

\begin{abstract}
The aim of this paper is a comparative analysis of legislative solutions and practical application of the public consultations in the Polish local government after 1989. The legal changes that occurred during this period have guaranteed Polish citizens the tool to direct exercising the political power. Unfortunately, the lack of legislative precision in the use of mechanisms of civic participation in Poland is characteristic of public consultation. Despite the fact that this solution has been used by public administration since the political-system transformation and the passing of the Act on Gmina Self-Government of 1990, and that in 1997 the consultations as a form of the exercise of power by the citizens were also established in the Constitution, for the first two decades there was a fairly great freedom of interpretation in holding them, which the local self-government authorities widely used. Positive changes in the practice of using the mechanisms of public consultation in Poland, including the formulation of the widely accepted set of guidelines and practical advice concerning the manner of implementing these mechanisms, began to take place only in the last four to five years. Main thesis of the paper is the opinion that public consultations in the example of the Polish self-government despite nearly three decades of legislative and political experiences are still not an effective tool of direct democracy, but only a bureaucratic facade.
\end{abstract}

Key words: public consultations, self-government in Poland, direct democracy

\section{INTRODUCTION}

The purpose of this paper is to attempt to answer the question of the scope of legislative solutions and practical application of the public consultations in the Polish local self-government after 1989. The legal changes that occurred during last three decades have guaranteed Polish citizens an instrument to direct exercising the political power. Unfortunately, one of characteristics of Polish public consultation is the lack of legislative precision in the aspect of applying mechanisms of civic participation. Despite the fact that this legal solution has been used by public administration since the political-system transformation, there is a fairly great freedom of interpretation in applying them. This freedom is extensively used by local self-government authorities. Positive changes in the practice of using the mechanisms of public consultation in Poland, including the formulation of the widely accepted set of guidelines and practical advice concerning the manner of implementing these mechanisms, began to take place only in the last five years. Main thesis of the presentation is the opinion that public consultations in Polish self-government despite nearly three decades of legislative and political experiences are still not an effective tool of direct democracy rather a bureaucratic facade.

The concept of the public consultations is understood in the paper as an instrument of engaging citizens in decision-making and thus as a form of at least indirect governance in the state, both at the 
government and local self-government level. It is important to remember that public consultation is a coordinated and rule-based procedure. The conviction that (1) consultations should be conducted in the spirit of civil dialogue and mutual understanding; (2) information about their purposes, rules or progression must be publicly available; and 3) anyone interested in the topic can express their own opinion and receive answers to their doubts within a reasonable time, are the standards of a democratic state of law. However, not every authority using this instrument attempts to remember that public consultations should be conducted both on the basis of clear rules, and that their organizers, though entitled to express their views, should organize the procedure for the public interest and general good in a broader sense ${ }^{1}$.

\section{LEGAL FOUNDATIONS FOR PUBLIC CONSULTATION IN POLISH LOCAL SELF-GOVERNMENT}

One of the most visible features of the Polish legal system in the context of public consultation procedure is the lack of direct regulation of the latter. The procedure was not directly legislated in the current Constitution of Poland adopted on 2 April 1997. There is even no comprehensive act of law on this issue. This procedure indirectly derives from a number of general constitutional principles including: (a) rule of law principle that "The Republic of Poland shall be a democratic state ruled by law and implementing the principles of social justice" (article 2); (b) popular sovereignty principle that "Supreme power in the Republic of Poland shall be vested in the Nation" (article 4); (c) the principle of social dialogue as the foundation of various forms and methods of cooperation between administration and social partners (Preamble); and (d) the principle of subsidiarity as an element ensuring citizens' priority in solving social problems (Preamble), which is especially important from the local self-government point of view. The supporters of public consultations also refer to the fragments of the constitution defining elementary rules of access to information on the activity of public authorities, in particular to article 54 according to which "The freedom to express opinions, to acquire and to disseminate information shall be ensured to everyone" as well as to article 61 that " 1 . A citizen shall have the right to obtain information on the activities of organs of public authority as well as persons discharging public functions. Such right shall also include receipt of information on the activities of self-governing economic or professional organs and other persons or organizational units relating to the field in which they perform the duties of public authorities and manage communal assets or property of the State Treasury. 2. The right to obtain information shall ensure access to documents and entry to sittings of collective organs of public authority formed by universal elections, with the opportunity to make sound and visual recordings"'.

Before accepting the constitution, the public consultation procedure was the subject of a law adopted by the communist authorities in 1987. The Act on public consultation and referendum was in force during the systemic transformation in Poland and was finally repealed in 1995. Pursuant to the provisions of the Act, public consultations were allowed to be organized in order to consult the

1 MAKOWSKI, G. Konsultacje publiczne - uregulowania prawne a praktyka. In Infos. Zagadnienia społeczno-gospodarcze. Vol. 20 (2014), p. 1 - 4.

2 The Constitution of the Republic of Poland of 2nd April 1997. Law No. 78, Item 483 (1997). 
society on "matters of crucial importance for the development of a country, a specific area or interests and conditions" (article 1). The Act has been so far the only legal enactment in Polish legislation, which set out detailed rules for conducting public consultations, including: the form of initiating consultations, the scope of responsibility for their reliability or the principles of substantive supervision over consultations ${ }^{3}$. Therefore, many rules related to the practice of conducting consultations have remained in common use even after the Act was repealed.

The direct legal basis for conducting public consultations in Poland is included in three local self-government laws: (1) The Act on Commune Self-Government (2) The Act on County SelfGovernment (3) The Act on Voivodship Self-Government. In each of the laws there are almost identical provisions on public consultations, referring to particular levels of the Polish self-government: gmina (commune), powiat (county), województwo (voivodship). Under these legal acts, public consultations can be carried out in two cases: (a) in matters provided by law (obligatory); and (b) in other matters important to the local self-government (facultative). In the case of principles and detailed procedure of conducting consultations, the legislator secured freedom for local authorities, making self-government legislative bodies responsible for determining these bases. They have to specify, among others: formal requirements that public consultation projects should fulfill; the rules for the assessment of notified projects in terms of compliance with law, technical feasibility or formal requirements; the rules on voting and determination of results; as well as the rules for making the results public, taking into account that the voting principles must ensure equality and directness of the vote ${ }^{4}$.

In the case of the Lubelskie Voivodship, the fundamental document defining the framework for conducting public consultations is the annual Local Self-Government Program of Cooperation with Non-Governmental Organizations and Other Entities Carrying Out Public Benefit Activities. Chapter 12 of the programme details the scope of consultative competences available to non-governmental organizations. Public benefit entities may, inter alia:

1. express opinions on matters concerning the functioning of non-governmental organizations;

2. apply to local authorities with proposals for legal solutions regarding the participation of the non-governmental sector in the processes of consulting local self-government tasks;

3. apply to local self-government authorities with proposals for legal solutions regarding the procedures for implementing commissioned local self-government tasks;

4. create and consult strategic programmes;

5. express opinions on draft local law acts;

6. notify any planned activities to each other;

7. participate in the development of the project of the Local Self-Government Cooperation Programme ${ }^{5}$.

Usually, local self-government is the party which initiates such public consultations, however this can be done on the request of the either side. The consultative procedure is most often carried

3 The Act on Public Consultation and Referendum of $6^{\text {th }}$ May 1987. Law No. 14, Item 83 (1987).

4 The Act on Commune Self-Government of 8th March 1990. Law No. 16, Item 95 (1990), article 5a. The Act on County Self-Government of 5th June 1998. Law No. 91, Item 578 (1998), article 3d. The Act on Voivodship Self-Government of 5th June 1998. Law No. 91, Item 576 (1998), article 10a.

5 Resolution on 'Lubelskie Voivodship Local Self-Government Program of Cooperation with Non-Governmental Organizations and Other Entities Carrying Out Public Benefit Activities in 2018' of $7^{\text {th }}$ December 2017. Law Item 4906 (2017), article 14 . 
out in very specific situations specified by law. Polish legislation allows public consultations on the following issues:

1. Creation of annual as well as long-term cooperation programmes with public benefit organizations by self-government authorities ${ }^{6}$.

2. Formulation of spatial layout plans as well as studies of conditions and directions for development planning?

3. Creation of projects for the development strategy of Local Self-Government Units ${ }^{8}$.

4. Implementation of investments affecting the environment ${ }^{9}$.

5. Making changes in the boundaries of local self-government units ${ }^{10}$.

6. Formulation of strategies for solving social problems ${ }^{11}$.

In the Polish legislative and political practice the citizens may take part in public consultations in two ways: directly or by the medium of their representative bodies. It is worth noting here that it is quite common practice for the Polish local self-government to carry out simultaneous public consultations in both ways. The first way is understood as a general consultation. The procedure for conducting such consultation begins with the publication of the draft regulations as well as the summary of their impact assessment on official local self-government website. Residents of the local self-government unit have the right to submit comments to the regulation. Such a notification can be made via e-mail, post or directly at the office within a specified period of time, which is usually 14 or 21 days. The department accountable for proposed regulation is required to consider any comments and corrections. A final report is prepared from the consultation. The document contains information on the following: time and place of the procedure; number of submitted comments; characteristics of the proposed changes; as well as the justification for accepting or rejecting such changes by the applicant of new regulations. The final report is submitted to the authorities of the local self-government unit by the accountable department, and after its approval it is made public via the official website.

The basis for the second method of conducting public consultations in the Polish local selfgovernment is the idea of creating joint official bodies in which representatives of non-governmental organizations and representatives of local self-government administration cooperate with each other. Such bodies operate with local self-government permanently or for the duration of a specific task, and their main task is to give opinions on new regulations for the needs of the local self-government administration. The inclusion of the so-called 'social factor' - representatives of non-governmental organizations in the official structure has to ensure the permanent presence of a citizens voice in the activities of local self-government authorities. From the perspective of the voivodship self-government the most important representative bodies are The Voivodship Social Dialogue Council (Wojewódzka Rada Dialogu Społecznego) and The Voivodship Council for Public Benefit Work (Wojewódzka Rada Działalności Pożytku Publicznego).

The Act on Public Benefit and Volunteer Work of 24 $4^{\text {th }}$ April 2003. Law No. 96, Item 873 (2003), article 5a.

7 The Act on Spatial Planning and Land Development of $27^{\text {th }}$ March 2003. Law No. 80, Item 717 (2003), article $49 f$.

8 The Act on the Principles of Conducting Development Policy of $6^{\text {th }}$ December 2006. Law No. 227, Item 1658 (2006), article 6 .

9 The Act on Sharing Information about the Environment and its Protection, Public Participation in Environmental Protection and Environmental Impact Assessments of $3^{\text {rd }}$ October 2008. Law No.199, Item 1227 (2008), articles 110, 115.

10 The Act on Commune Self-Government of $8^{\text {th }}$ March 1990. Law No. 16, Item 95 (1990), article 4a. The Act on County Self-Government of $5^{\text {th }}$ June 1998. Law No. 91, Item 578 (1998), article 3a.

11 The Act on Social Assistance of $12^{\text {th }}$ March 2004. Law No. 64, Item 593 (2004), articles 19, 21. 
The Voivodship Social Dialogue Councils are institutions intended for cooperation between employees, employers, local self-government and government representatives appointed on the basis of the Act on the Social Dialogue Council and other institutions of social dialogue of 24 July 2015. The most important tasks of such Councils are: (1) negotiating social and economic issues causing conflicts between employees and employers; (2) expressing opinions and positions on matters within the scope of tasks of trade unions or employers' organizations; (3) expressing opinions on voivodship development strategy projects and other programmes within the scope of tasks of trade unions and employers' organizations. In the case of the Voivodship Social Dialogue Council operating in the Lublin Voivodship, the institution was established by the Marshal (the Head of the Local Self-Government Executive) in December 2015. It consists of 30 people. The chairmanship of the Council has a rotational nature. In the first term of office (2016), the employee's representative was the Chairman; in the second (2017) - a representative of local self-government. In the current third term of office (2018), the function of the Chairman is represented by employers, and in 2019 a representative of the Polish government will take it over ${ }^{12}$.

The Voivodship Councils for Public Benefit Work are consultative, advisory and auxiliary institutions of self-government authorities. They are created on the basis of the Act on Public Benefit and Volunteer Work of 24 April 2003. On the joint request of at least 50 non-governmental organizations the Marshal of the Voivodship may establish the institution. The Council is composed of: a representative of the Voivode (Province Governor, representative of the Polish government), representatives of the local self-government executive (The Management Board of the Lubelskie Region) and legislative (The Voivodship Council), as well as the representatives of non-governmental organizations. At the same time, the representatives of non-governmental organizations that operate locally, form at least one half of the Council. The non-governmental organizations included in the Council must also have the status of a 'public benefit organization', so they do not run a business and have been active in legally defined 'public benefit work areas' for at least two years. The tasks of the Council should include in particular "(1) issuing opinion on matters pertaining to the activity of non-governmental organizations, including cooperation programmes with non-governmental organizations; (2) issuing opinion on draft resolutions and draft acts of local law on public tasks; (3) offering assistance and issuing opinions in case of any dispute between public administration authorities and non-governmental organizations; (4) issuing opinion on matters concerning public tasks, on the process of commissioning such tasks to be performed by non-governmental organizations and on recommended public task performance standards; (5) issuing opinion on the projects of the development strategy for the voivodship." Debates of the Voivodship Council take place during meetings and the term of office of a Voivodship Council is three years ${ }^{13}$.

\section{$3 \quad$ PRACTICAL ASPECTS OF PUBLIC CONSULTATION IN POLISH LOCAL SELF-GOVERNMENT}

The lack of legislative precision in the application of mechanisms of civic participation in Poland was expressed by the authors of the report as part of the Study on the Effectiveness of Mechanisms

12 The Act on the Social Dialogue Council and other institutions of social dialogue of $24^{\text {th }}$ July 2015. Law Item 1240 (2015).

13 The Act on Public Benefit and Volunteer Work of $24^{\text {th }}$ April 2003. Law No. 96, Item 873 (2003), articles 41 a, 41 b, $41 \mathrm{c}$. 
for Public Consultation. The document was commissioned in 2010 by the Ministry of Labor and Social Policy and analyzed the practices carried out at the central (government) and local (voivodship, county, commune) levels. The authors have formulated several dozen remarks pertaining to the quality of public consultations conducted in Poland. The conclusions regarding the quality of public consultations at the voivodship level were as follows:

1. Public consultations at the regional level are carried out mainly by Marshal Offices, much less frequently by Province Governor's Offices

2. There is no uniform mechanism for conducting public consultations in the offices.

3. Public consultations are usually treated as an obligation resulting from legal regulations rather than as a form of building permanent structures of cooperation with citizens. The effect of such an approach may be façade management that has no impact on the decision-making process.

4. The consultations are usually conducted in cases in which directly required by law. Cases of 'spontaneous' consultations are rare.

5. There is relatively high awareness of the role of civil dialogue in making decisions about public matters, often accompanied by positive attitude towards social consultations, which does not reflect into specific actions.

6. There are preferences for passive ways of seeking opinions, consisting in the placing of information on consultations exclusively on the websites of the Bulletin of Public Information and on the notice boards in the offices, and in waiting for comments ${ }^{14}$.

The chairman of the Voivodship Councils for Public Benefit Work of the Lubelskie Voivodship Ms. Małgorzata Gromadzka agrees with the above remarks. According to her opinion, the fundamental problem of public consultations in the local self-government is the lack of mutual will to carry them out. The little innovative nature of the procedure discourages citizens from becoming involved in it. Basing consultations only on questionnaires without the opportunity to meet face-to-face bores citizens and strengthens them in the belief that their opinion has no real impact on the legislative process. On the other hand, self-government administration is equally skeptical about consultations, treating them as a necessity extending the legislative process. Therefore, information about public consultations is popularized in an insufficient manner only through the website or bulletin board at the office ${ }^{15}$.

Furthermore, the analysis of the quality of public consultations conducted at the county and commune levels (powiat and gmina) showed that citizens are interested in consultations, especially regarding regulations affecting their own lives, but they cannot refer these procedures to the overly technical language of various types of documents or strategies. Moreover, the vast majority of offices at these levels do not have a dedicated organizational unit that conducts public consultations. Such entity is only present in $6 \%$ of counties and $8 \%$ of communes. Consultations are more often organized in urban communes than in rural ones. Dedicated organizational units that conducts public consultations exist in $43 \%$ of the former and $7 \%$ of the latter ${ }^{16}$. The distinctive popularity of public consultations in urban communes is most likely the result of growing interest in the participatory budget, which according to Polish law is treated as a 'special form of public consultation' ${ }^{17}$.

14 CELIŃSKI, A. et al. Wyimki z raportu końcowego badania efektywności mechanizmów konsultacji społecznych. Warszawa: Pracownia Badań i Innowacji Społecznych Stocznia, 2011, p. 10 - 11 [hereafter as CELIŃSKI (2011a)].

15 The interview with Ms. Małgorzata Gromadzka held in Lublin on May 18, 2018. Author's own archive.

16 CELIŃSKI (2011a) ibid., p. 11.

17 The Act on County Self-Government of $5^{\text {th }}$ June 1998. Law No. 91, Item 578 (1998), article 3d, The Act on Voivodship Self-Government of $5^{\text {th }}$ June 1998. Law No. 91, Item 576 (1998), article 10a. 
On the basis of questionnaire surveys conducted in commune and county offices, the authors of the report also concluded that in the case of over one third of local self-governments the practice of the use of public consultation was considered only as a troublesome necessity. When asked about the number of consultation procedures carried out by a given unit during the last two years, $37 \%$ of local self-government units admitted that the number was from one to three procedures. A comparable percent (34\%) said the number of conducted consultations ranged between four and ten procedures. Only $15 \%$ of local self-governments admitted that they had conducted eleven or more public consultations in the last 24 months while at the same time almost the same percent of the offices surveyed (14\%) were entirely unable to give the number of conducted consultations. A detailed analysis of the results showed as well that the most popular forms of inquiry in public consultations are 'the most traditional ones' as submitting written applications by post, reporting verbally to the official during the office's working hours and submitting written applications directly to the office ${ }^{18}$.

\begin{tabular}{|l|c|c|c|c|c|c|}
\hline & Never & Rarely & $\begin{array}{c}\text { Half } \\
\text { of the } \\
\text { cases }\end{array}$ & Often & Always & $\begin{array}{c}\text { I do not } \\
\text { know }\end{array}$ \\
\hline $\begin{array}{l}\text { Submitting written } \\
\text { applications by traditional } \\
\text { mail or by fax }\end{array}$ & $4 \%$ & $5 \%$ & $9 \%$ & $14 \%$ & $65 \%$ & $3 \%$ \\
\hline $\begin{array}{l}\text { Submitting applications } \\
\text { by e-mail }\end{array}$ & $13 \%$ & $10 \%$ & $11 \%$ & $12 \%$ & $50 \%$ & $4 \%$ \\
\hline $\begin{array}{l}\text { Submitting applications } \\
\text { via internet forums, chats } \\
\text { and other forms of elec- } \\
\text { tronic communication }\end{array}$ & $59 \%$ & $8 \%$ & $6 \%$ & $8 \%$ & $16 \%$ & $4 \%$ \\
\hline $\begin{array}{l}\text { Individual meetings } \\
\text { with interested persons } \\
\text { and institutions }\end{array}$ & $13 \%$ & $11 \%$ & $15 \%$ & $21 \%$ & $35 \%$ & $5 \%$ \\
\hline $\begin{array}{l}\text { Reporting verbally } \\
\text { to the official during the } \\
\text { offices working hours }\end{array}$ & $10 \%$ & $9 \%$ & $10 \%$ & $12 \%$ & $53 \%$ & $6 \%$ \\
\hline $\begin{array}{l}\text { Submitting written } \\
\text { applications directly } \\
\text { to the office }\end{array}$ & $3 \%$ & $5 \%$ & $8 \%$ & $11 \%$ & $70 \%$ & $4 \%$ \\
\hline $\begin{array}{l}\text { Submitting phone } \\
\text { applications directly } \\
\text { to the official }\end{array}$ & $75 \%$ & $5 \%$ & $4 \%$ & $4 \%$ & $9 \%$ & $3 \% \%$ \\
\hline $\begin{array}{l}\text { Filing the application by } \\
\text { phone via the hotline }\end{array}$ & $12 \%$ & $10 \%$ & $12 \%$ & & \\
\hline
\end{tabular}

18 CELIŃSKI, A. et al. Raport końcowy z badań efektywności mechanizmów konsultacji społecznych. Warszawa: Pracownia Badań i Innowacji Społecznych Stocznia, 2011, p. 117 - 118, 128 [hereafter as CELIŃSKI (2011 b)]. 


\begin{tabular}{|l|c|c|c|c|c|c|}
\hline & Never & Rarely & $\begin{array}{c}\text { Half } \\
\text { of the } \\
\text { cases }\end{array}$ & Often & Always & $\begin{array}{c}\text { I do not } \\
\text { know }\end{array}$ \\
\hline $\begin{array}{l}\text { Open meetings and } \\
\text { conferences }\end{array}$ & $12 \%$ & $11 \%$ & $21 \%$ & $22 \%$ & $30 \%$ & $3 \%$ \\
\hline $\begin{array}{l}\text { Meetings of working } \\
\text { groups }\end{array}$ & $13 \%$ & $12 \%$ & $19 \%$ & $21 \%$ & $30 \%$ & $4 \%$ \\
\hline $\begin{array}{l}\text { Gathering information } \\
\text { in informal everyday con- } \\
\text { tacts with representatives } \\
\text { of interested institutions }\end{array}$ & $27 \%$ & $13 \%$ & $15 \%$ & $14 \%$ & $24 \%$ & $7 \%$ \\
\hline $\begin{array}{l}\text { Consultation through } \\
\text { a permanent consultative / } \\
\text { advisory body }\end{array}$ & $48 \%$ & $10 \%$ & $9 \%$ & $10 \%$ & $15 \%$ & $8 \%$ \\
\hline Other forms & $83 \%$ & $3 \%$ & $1 \%$ & $1 \%$ & $1 \%$ & $11 \%$ \\
\hline
\end{tabular}

Chart 1: The use of various forms of inquiry in public consultations in Poland ${ }^{19}$

Positive changes in the practice of applying the mechanisms of public consultation in Poland began to take place only in the last years. A few main directions of these changes can be indicated. The first one is the efforts carried out jointly by scientists and local government officials to improve the quality of social consultations through their more careful and detailed preparation. An example of such activities is the scientific project New Perspectives for Dialogue: A Model of Deliberation and ICT Tools for Social Inclusion in Decision-making Processes conducted between the years 2014-2017 by the University of Warsaw; the Warsaw University of Technology; the Association of Polish Cities; the Foundation of Free and Open Software and the Polish Forum of Disabled People. The aim of the project was to develop a model of social dialogue and innovative IT tools that will enable its implementation. However, the practical effect of the actions was to propose specific services and develop procedures related to the public consultation process, as well as the creation of new products, including an online platform enabling social dialogue and consultations via internet. So-called 'the inDialogue application' has been used successfully in 2017 in pilot studies in ten municipalities in different regions of Poland, including: Olsztyn, Brwinów, Mińsk Mazowiecki, Krosno, Słupsk and Torun $^{20}$. The proposed application has gathered a number of positive opinions both among representatives of non-governmental organizations and the international scientific community. Reviewing the project Stephen Coleman, Professor of Political communication at the University of Leeds called inDialogue "a tool that can be used by local administrations in Poland and beyond" ${ }^{21}$.

The second positive change is an effort undertaken by the Polish government focused on the formulation of the widely accepted set of guidelines and practical advice concerning the manner of

19 CELIŃSKI (2011 b) ibid., p. 128.

20 PRZYBYLSKA, A. inDialogue software for the good quality of public consultations. The model for action. In The project inDialogue website, 2017, p. 1 - 2 [online]. Available at <http://wdialogu.uw.edu.pl $>$. [q. 2018-09-20].

21 COLEMAN, S. In Dialogue - Some observations on a new platform for local government online consultations. In The project inDialogue website, 2015 [online]. Available at $<$ http://wdialogu.uw.edu.pl>. [q. 2018-09-20]. 
implementing the mechanisms of public consultation. One of the most significant actions improved the quality of public consultations in the Polish local self-government was taken by The Chancellery of the President of Poland. The office prepared in late 2013 so-called Canon of Local Public Consultations. Although the canon has not been laid down in the legislation, it is a commonly accepted practice, defining inter alia seven cardinal principles of public consultation, which would be a guideline for the offices in the use of the procedure. The document embraces the requirement of planning public consultations in the spirit of:

1. Good faith i.e. agreement, the will to accept different arguments, and dialogue between the parties.

2. Universality, according to which every citizen should be provided with information about consultations and have an opportunity to express his/her opinion in them.

3. Transparency consisting in universal access to the goals, rules, course and results of consultations.

4. Responsiveness, under which local self-government offices are obliged to give a factual answer to everyone submitting an opinion.

5. Coordination, which specifies the administratively empowered 'host'-manager responsible for consultations in organizational and political terms.

6. Predictability, according to which local self-government offices are under the obligation to conduct consultations in a planned way from the beginning of the legislative process.

7. Respect for general interest, which obliges both officials and consultation participants to act in the spirit of public interest ${ }^{22}$.

The last but not least positive change in the practice of applying the mechanisms of public consultation is the spread of the idea of establishing permanent consultative and advisory bodies in the public administration units. A good example of such are the Councils for Public Benefit Work, mentioned above. They have been established with all sixteen Marshal Offices in Poland as well as at the central level as a consultative-advisory agency of the Minister of Family, Labor, and Social Policy. The role of these bodies in local self-government increases gradually. In 2017, the Voivodship Council for Public Benefit Work of the Lubelskie Voivodship issued binding opinions in the case of 17 acts of local law. In 2018, a similar number of cases (16) were already approved by the Council in the first half-year, which allows us to observe the growing importance of this body In the cases of counties and communes it is only in recent years that there has been an observable heightened interest in this form of public consultation. The leading role is still played by urban units, which, already in 2011, set up local Councils of Public Benefit Work three times as often as rural ones. The structures of urban counties and communes also more often contained other consultative bodies. In the foregoing year, two thirds of urban counties had such a solution in their structure, twice as often as rural counties and three times as often as communes $\mathrm{did}^{23}$.

22 Siedem zasad konsultacji społecznych. In Kanon Lokalnych Konsultacji Społecznych [online]. Available at $<$ http://www. kanonkonsultacji.pl>. [q. 2018-09-21].

23 CELIŃSKI (2011 b) ibid., p. $81-82$. 


\section{CONCLUSION}

Undoubtedly, the fundamental sign of positive changes in the practice of using the mechanisms of public consultation in Polish local self-government is the growing popularity of the participatory budgeting as well. In 2011 this procedure was conducted for the first time in Poland by city authorities of Sopot, which allowed residents to distribute the amount of 7 million PLN. Five years later, similar solution was adopted by 58 local self-governments and the total value of funds which had to be distributed within amounted to 318.5 million $\mathrm{PLN}^{24}$. The numerical data shows exquisitely that public consultations are still a socially desirable instrument in local self-government, because citizens want to have a real impact on political decisions that shape their lives. They only need effective solutions for this. Examples of the inDialogue application, the Council for Public Benefit Work as well as the participatory budgeting show the necessity of constant work on new forms of citizens' involvement in public sphere. Therefore, the potential for such 'public consultation' requires not only the involvement of citizens, but also the support of the government, local self-governments as well as the political elite, because the social enthusiasm can only be absorbed within a clearly and precisely defined legal and political framework.

\section{Bibliography:}

CELIŃSKI, A. et al. Raport końcowy z badań efektywności mechanizmów konsultacji społecznych. Warszawa: Pracownia Badań i Innowacji Społecznych Stocznia, 2011.

CELIŃSKI, A. et al. Wyimki z raportu końcowego badania efektywności mechanizmów konsultacji społecznych. Warszawa: Pracownia Badań i Innowacji Społecznych Stocznia, 2011.

COLEMAN, S. In Dialogue - Some observations on a new platform for local government online consultations. In The project inDialogue website, 2015 [online]. Available at <http://wdialogu.uw.edu.pl>. [q. 2018-09-20].

KRASZEWSKI, D. MOJKOWSKI, K. Budżet obywatelski w Polsce. Warszawa: Fundacja im. Stefana Batorego, 2014.

MAKOWSKI, G. Konsultacje publiczne - uregulowania prawne a praktyka. In Infos. Zagadnienia społeczno-gospodarcze. Vol. 20 (2014).

PRZYBYLSKA, A. inDialogue software for the good quality of public consultations. The model for action. In The project inDialogue website, 2017 [online]. Available at <http://wdialogu.uw.edu.pl>. [q. 2018-09-20].

Resolution on 'Lubelskie Voivodship Local Self-Government Program of Cooperation with Non-Governmental Organizations and Other Entities Carrying Out Public Benefit Activities in 2018' of $7^{\text {th }}$ December 2017. Law Item 4906 (2017).

Siedem zasad konsultacji społecznych. In Kanon Lokalnych Konsultacji Społecznych [online]. Available at <http:// www.kanonkonsultacji.pl>. [q. 2018-09-21].

The Act on Commune Self-Government of $8^{\text {th }}$ March 1990. Law No. 16, Item 95 (1990).

The Act on County Self-Government of $5^{\text {th }}$ June 1998. Law No. 91, Item 578 (1998).

The Act on Public Benefit and Volunteer Work of $24^{\text {th }}$ April 2003. Law No. 96, Item 873 (2003).

The Act on Public Consultation and Referendum of $6^{\text {th }}$ May 1987. Law No. 14, Item 83 (1987).

The Act on Sharing Information about the Environment and its Protection, Public Participation in Environmental Protection and Environmental Impact Assessments of $3^{\text {rd }}$ October 2008. Law No.199, Item 1227 (2008).

24 KRASZEWSKI, D., MOJKOWSKI, K. Budżet obywatelski w Polsce. Warszawa: Fundacja im. Stefana Batorego, 2014, p. 4 - 5. Budżety 2016. In Fundacja Instytut Myśli Innowacyjnej [online] <http://budzetyobywatelskie.pl/>. [q. 2018$09-21]$. 
The Act on Social Assistance of $12^{\text {th }}$ March 2004. Law No. 64, Item 593 (2004).

The Act on Spatial Planning and Land Development of $27^{\text {th }}$ March 2003. Law No. 80, Item 717 (2003).

The Act on the Principles of Conducting Development Policy of $6^{\text {th }}$ December 2006. Law No. 227, Item 1658 (2006). The Act on the Social Dialogue Council and other institutions of social dialogue of $24^{\text {th }}$ July 2015 . Law Item 1240 (2015).

The Act on Voivodship Self-Government of $5^{\text {th }}$ June 1998. Law No. 91, Item 576 (1998).

The Constitution of the Republic of Poland of $2^{\text {nd }}$ April 1997. Law No. 78, Item 483 (1997).

\section{Contact information:}

Marcin Pomaranski, PhD.

mpomaran@gmail.com

Maria Curie-Sklodowska University in Lublin

Pl. M. Curie-Sklodowskiej 5

20-031 Lublin

Lublin

Poland 